DOI: https://doi.org/10.24127/ajpm.v10i4.4151

\title{
ANALISIS KESALAHAN KONTRUKSI KONSEP PADA MATERI BANGUN RUANG SISI DATAR BERDASARKAN PEMBERIAN SCAFFOLDING
}

\author{
Septiani Wulandari ${ }^{1^{*}}$, Kamid ${ }^{2}$, Haryanto $^{3}$ \\ ${ }^{1,2}$ Pendidikan Matematika Universitas Jambi, Jambi, Indonesia \\ $3^{*}$ Pendidikan Kimia Universitas Jambi, Jambi, Indonesia \\ *Corresponding author. Jambi. 36146, Jamb, Indonesia. \\ E-mail: $\quad \underline{\text { septianiwlndry@gmail.com }}^{1 *}$ \\ kamid.fkip@unja.ac.id $^{2)}$ \\ $\underline{\text { haryanto.fkip@unja.ac.id }}^{3)}$
}

Received 24 August 2021; Received in revised form 17 November 2021; Accepted 30 December 2021

\begin{abstract}
Abstrak
Penelitian ini bertujuan untuk menganalisis kesalahan siswa dalam mengkontruksi konsep pada materi bangun ruang sisi datar berdasarkan pemberian scaffolding. Jenis penelitian ini adalah penelitian deskriptif kualitatif. Teknik pengambilan sampel dalam penelitian ini menggunakan teknik purposive sampling. Subjeknya adalah siswa Kelas VIII, dan subjek dalam penelitian ini menemukan tiga subjek yang mewakili keterampilan tinggi, sedang, dan rendah. Instrumen yang digunakan dalam penelitian ini adalah soal tes dan lembar wawancara. Data yang diperoleh dianalisis melalui (1) langkah-langkah mereduksi data. (2) Menyajikan data, yaitu memilah jenis kesalahan yang dibuat siswa karena kesalahan. (3) Menarik kesimpulan, yaitu melakukan kegiatan sesuai dengan konsep masing-masing siswa tentang kelemahan konstruksi, atau menyajikan scaffolding. Hasil penelitian ini kesalahan kontruksi konsep pada indikator pseudo contruction "Benar" yang terjadi pada SE1 dan SE2 scaffolding yang sesuai adalah tahap pengembangan konseptual. indikator pseudo contruction "Salah" yang terjadi pada SE1 scaffolding yang sesuai adalah tahap pengembangan konseptual. Indikator lubang kontruksi seperti yang terjadi pada semua subjek scaffolding yang sesuai adalah tahap Explaining.mis-analogical contruction yang terjadi pada SE3 scaffolding adalah tahap restructuring. Indikator mis-logical contruction terjadi pada SE3 scaffolding yang sesuai adalah tahap Reviewing.
\end{abstract}

Kata kunci: Kesalahan Kontruksi Konsep; Materi Bangun Ruang Sisi Datar; Pemberian Scaffolding

\begin{abstract}
This study aims to analyze student errors in constructing concepts in the flat-sided building material based on the provision of scaffolding. This type of research is descriptive qualitative research. The sampling technique in this study used a purposive sampling technique. The subjects were Class VIII students, and the subjects in this study found three subjects representing high, medium, and low skills. The instruments used in this study were test questions and interview sheets. The data obtained were analyzed through (1) data reduction steps. (2) Presenting data, namely sorting out the types of errors made by students due to errors. (3) Drawing conclusions, namely carrying out activities according to each student's concept of construction weaknesses, or presenting scaffolding. The result of this research is that the error in the construction of the concept on the "True" pseudo construction indicator that occurs in SE1 and SE2 of the appropriate scaffolding is the conceptual development stage. the indicator pseudo construction "Wrong" that occurs in the appropriate SE1 scaffolding is the conceptual development stage. The construction hole indicator as happened in all suitable scaffolding subjects is the Explaining stage. Mis-analogical construction that occurs in SE3 scaffolding is the restructuring stage. An indicator of mis-logical construction that occurs in the appropriate SE3 scaffolding is the Reviewing stage.

Keywords: Concept Construction Errors; Flat Side Space Building Materials; Scaffolding
\end{abstract}

This is an open access article under the Creative Commons Attribution 4.0 International License 
DOI: https://doi.org/10.24127/ajpm.v10i4.4151

\section{PENDAHULUAN}

Pendidikan di Indonesia secara umum masih berorientasi pada nilai ujian. Oleh karena itu, sudah saatnya pembenahan sistem pendidikan di Indonesia, karena tidak dapat memenuhi kebutuhan zaman. Penanaman nilai karakter pada siswa berdasarkan kurikulum 2013 merupakan langkah awal untuk meningkatkan tujuan pendidikan bangsa Indonesia dapat dilihat pada abad 21 (Suratno \& Sari, Prawitha, 2021). Abad ke-21, juga dikenal sebagai abad 4.0 Revolusi Industri, merupakan abad perkembangan ilmu pengetahuan dan teknologi yang pesat. Singkatnya, orang perlu memiliki kemampuan untuk memasukkan keterampilan 4C ke dalam proses pembelajaran abad ke-21: kreativitas, pemikiran kritis, komunikasi, dan kolaborasi (Sari \& Trisnawati, 2019).

Menurut (Faradillah \& Febriani, 2021), Matematika dianggap sebagai dasar ilmu pengetahuan dan teknologi. Ini sangat mata pelajaran penting di sekolah menengah, oleh karena itu setiap negara menerapkan matematika untuk mendukung perkembangan ilmu pengetahuan dan teknologi. Matematika memiliki peranan penting dalam kehidupan sehari-hari, karena banyak kegiatan yang melibatkan matematika. Matematika memiliki peran penting dalam proses pengembangan pemikiran manusia karena matematika dan penalaran tidak dapat dipisahkan (Crosby et al., 2018). Konsep matematika (Amelia, Anwar, \& Firdos, 2021) perlu dikonstruksi oleh siswa. Oleh karena itu, membangun sebuah konsep berarti menciptakan sebuah konsep. Membangun konsep matematika merupakan kegiatan aktif untuk memperoleh atau membuat konsep matematika, namun pada kenyataannya masih banyak terjadi kesalahan dalam membangun konsep, sehingga diperlukan scaffolding yang dapat menunjang kebutuhan memenuhi siswa (Abdu, Schwarz, \& Mavrikis Manolls, 2015).

Bangun ruang sisi datar adalah bangun ruang yang memiliki sisi berbentuk mendatar. Adapun materi bangun ruang sisi datar kelas VIII menentukan rumus dan luas permukaan balok dan kubus (Kemendikbud, 2017). Pengaplikasiaan balok dan kubus dapat dilihat dari contoh nyata salah satunya adalah budaya jambi, berdasarkan (Kamid \& Yuliya, 2020). Siswa dapat menentukan permukaan kubus dan balok melalui proyek pembelajaran berbasis budaya Jambi. Unsur-unsur budaya Jambi yang terkait dengan bangun ruang sisi datar adalah sejarah Gentala Arasi, Candi Muaro Jambi dan Museum Shiginjai Jambi.

Berdasarkan literature hasil penelitian sebelumnya yang dilakukan (Ni \& Fathani, 2018) mengetahui jenis kesalahan konstruksi konsep matematika yang dilakukan siswa meliputi: (1) pseudo development, (2) lubang konstruksi, (3) mis-analogical development, dan (4) mis logical development. Kesalahan siswa dalam merumuskan konsep matematika perlu dibenahi. Salah satunya dengan menyediakan scaffolding sesuai dengan kebutuhan siswa. Menyediakan scaffolding membantu siswa mengembangkan pola pikir untuk menemukan hasil akhir yang tepat. Hal ini sejalan dengan penelitian yang dilakukan oleh (Susilowati \& Ratu, 2018) menemukan kesalahan siswa saat memecahkan masalah dan dapat memberikan dukungan bagi siswa yang mengalami kesulitan atau membuat kesalahan dalam belajar matematika atau materi lainnya. Hal ini sejalan 
DOI: https://doi.org/10.24127/ajpm.v10i4.4151

dengan pendapat (Komarudin, 2016) kesulitan siswa dalam proses pemecahan masalah dan pemberian scaffolding yang dilakukan dapat memberikan dampak positif pada siswa.

Scaffolding dapat mendukung berbagai tujuan pembelajaran termasuk menyerap konten dan konsep kursus, meningkatkan kesadaran diri, memberikan dukungan motivasi (Baranovich, Fong, \& Hutagalung, 2017). Scaffolding memahami cara menggunakan alat pembelajaran dan pengajaran seperti platform pembelajaran terkomputerisasi, dan teknik pembelajaran untuk beradaptasi dengan konteks pembelajaran yang berbeda (Brower dkk., 2017). (Sutiarso, 2009) menyatakan bahwa teori Vygotsky memperkenalkan mengenai konstruktivis sosial yang terdiri dua hal, yaitu belajar interaksi sosial dan zone of proximal development (ZPD). Konsep scaffolding ini sejalan dengan pendapat tentang (ZPD). Menurut pendapat ini, siswa dengan asisten dapat melakukan lebih dari yang mereka bisa jika pembelajaran dilakukan dalam pengembangan.

Berdasarkan hasil wawancara kepada salah seorang guru mata pelajaran matematika di SMP N 9 Kota jambi didapatkan informasi bahwa siswa mengalami kesalahan dalam mengkontruksi konsep matematika pada materi bangun ruang sisi datar. Hal ini dibuktikan ketiga guru memberi soal bangun ruang sisi datar didapatkan siswa memperoleh nilai di bawah KKM. Salah satu pemikiran tentang bagaimana siswa belajar, spesialnya mengonstruksi pengetahuan merupakan Teori Konstruktivisme. Konstruktivisme ialah suatu teori yang menekuni gimana seorang belajar. (Kusmaryono \& Ubaidah, 2020) Teori ini lebih memandang gimana belajar itu berlangsung. Sesuatu dikala siswa dapat secara maksimal mengonstruksi pengetahuan( diucap siswa konstruktif), pada dikala yang lain tidak konstruktif. Sebab itu belajar hafalan juga ialah suatu konstruksi, namun" konstruksi yang lemah" (Ni \& Fathani, 2018). Konstruksi lemah tampak sekali dari perilaku siswa yang kurang ingat dalam belajar dan tidak bisa memakai modul yang dipelajari buat menuntaskan kasus. Dalam Mengenai ini yang diingat oleh siswa hanya prosedur menyelesaikan soal, jika soal ditukar (meski sedikit) siswa sudah tidak mampu menyelesaikannya (Damayanti, 2016).

Untuk menyelesaikan suatu permasalahan matematika tersebut harus dilakukan scaffolding. (Kristanti Dian, 2020) Adapun level scaffolding tersebut, yaitu Level 1 adalah environmental provisions. Level 2 adalah explaining, reviewing, dan restructuring. Level 3 adalah conceptual development. Scaffolding bantuan yang memungkinkan peserta didik menyelesaikan tugas-tugas yang tidak dapat mereka selesaikan, dan bertujuan untuk membawa peserta didik lebih dekat ke tingkat kemampuannya, sehingga pada akhirnya mereka dapat menyelesaikan tugas-tugas tersebut mereka sendiri (Bakker, 2015).

Namun dari beberapa penelitian tersebut, belum banyak menggunakan scaffolding untuk mengatasi kesalahan kontruksi konsep siswa, khususnya pada materi bangun ruang sisi datar. Padahal faktanya berdasarkan data observasi awal yang ditemukan di lapangan, masih banyak siswa mengalami kesalahan dalam mengkontruksi soal matematika.

Oleh karena itu, berdasarkan uraian-uraian di atas, maka perlu scaffolding untuk mengatasi kesalahan siswa dalam mengkontruksi konsep 
DOI: https://doi.org/10.24127/ajpm.v10i4.4151

dengan harapan agar kesalahan kontruksi konsep matematika siswa berkurang.

\section{METODE PENELITAN}

Penelitian ini merupakan penelitian deskriptif kualitatif. Populasi dalam penelitian ini adalah siswa kelas VIII H SMP N 9 Kota Jambi yang berjumlah 3 siswa. Penelitian ini menggunakan kelas VIII sebagai objek penelitian maksimal 3 siswa, SE1, SE2 dan SE3, dimana 3 subjek memenuhi kriteria objek penelitian yaitu subjek yang paling banyak melakukan kesalahan 2 soal dan mampu bekerja dengan peneliti yang berpartisipasi dalam penelitian dan memiliki keterampilan komunikasi lisan yang baik.

Teknik penentuan subjek
penelitian menggunakan teknik
purposive sampling.

Pada penelitian ini langkah-langkah yang dilakukan adalah: Langkah pertama permintaan izin ke sekolah di
SMP N 9 Kota Jambi untuk melakukan penelitian, langkah kedua mempersiapakan instrument penelitian yaitu berupa soal tes dan pedoman wawancara, langkah ketiga memvalidasi soal tes dan pedoman wawancara, langkah keempat menentukan subjek penelitian, langkah kelima memberikan soal tes dan melakukan wawancara, langkah keenam menganlisis data, langkah ketujuh menyusun laporan penelitian.

Jenis instrument yang digunakan dalam penelitian ini adalah soal tes dan lembar wawancara. Instrument berupa soal tes yaitu terdiri dari 2 soal uraian. Materi yang diberikan yaitu materi bangun ruang sisi datar dengan indikator yang telah ditentukan. Adapun lembar wawancara pertanyaannya sesuai dengan indikator kesalahan kontruksi konsep (Tabel 1) dan wawancara yang dilakukan dalam penelitian ini tidak terstruktur.

Tabel 1. Jenis kesalahan kontruksi konsep dan indikator kesalahan kontruksi konsep (Ni'mah, Sunismi, \& Fathani, 2018)

Jenis kesalahan kontruksi konsep

Pseudo Construction

- Pseudo Construction"benar".

Siswa menuliskan jawaban yang benar, tetapi setelah ditelusuri, ternyata jawabannya salah.

- Pseudo Construction "salah"

Siswa menuliskan jawaban yang benar, tetapi setelah ditelusuri, ternyata jawabannya salah.Siswa menulis jawaban yang benar, tetapi pencarian mengungkapkan bahwa jawabannya salah.

\section{Lubang kontruksi}

Kesalahan kontruksi konsep yang dirasakan siswa diakibatkan oleh berpikir yang tercipta dalam proses konstruksi konsep tidak utuh.

\section{Indikator kesalahan kontruksi konsep}

Pseudo Construction"benar"

Siswa menuliskan jawaban yang benar untuk kasus tersebut. Namun, tindak lanjut mengungkapkan bahwa siswa salah mendistribusikan klasifikasi jawaban.

Pseudo Construction"salah"

Siswa membagikan jawaban salah terhadap permsalahan. Tetapi kala ditelusuri, siswa memiliki metode berfikir yang benar serta bisa membagikan jawaban yang benar.

Siswa membagikan jawaban benar, tetapi ada proses kontruksi konsep dalam siswa yang tidak cocok. 
DOI: https://doi.org/10.24127/ajpm.v10i4.4151

Jenis kesalahan kontruksi konsep

Indikator kesalahan kontruksi konsep

Siswa bisa menuntaskan soal yang terdapat dengan benar, tetapi proses kontruksi yang terdapat dalam benak siswa tidak cocok ataupun siswa hadapi kesalahan dalam mengonstruksi konsep yang menyebabkan konsep tidak tercipta secara utuh.

\section{Mis-analogical Construction}

Kesalahan kontruksi konsep terjadi ketika siswa membandingkan satu konsep dengan konsep lainnya. Misalnya, saat membuat akar dan eksponen, siswa menganggap operasi akar dan eksponen sama dengan operasi normal.

\section{Mis-logical Construction}

Kesalahan kontruksi konsep yang dihadapi siswa terbentuknya dari kesalahan dalam berpikir logis serta siswa kurang mengerti dalam memahami soal yang diberikan.

Siswa membagikan jawaban salah disebabkan siswa membandingkan sesuatu konsep dengan konsep yang lain.

Siswa membagikan jawaban yang salah disebabkan kemampuan menalar ataupun menguasai soal yang diberikan kurang baik.

Tabel 2. Level dan Indikator Scaffolding

\section{Level Scaffolding}

Level 1 environmental provisions.

Level 2 explaining, reviewing, dan restructuring.

Level 3 conceptual development.

\section{Indikator Scaffolding}

Level ini merupakan level scaffolding yang paling dasar. Pada tingkat ini, pembelajaran dapat dibantu dengan menyediakan lingkungan belajar untuk kelas. Tahap ini dapat dilakukan tanpa campur tangan guru. Misalnya, pengaturan tempat duduk dan pengaturan kelompok.

Level ini, guru membantu siswa memperdalam pemahaman mereka. Dalam hal ini guru akan menjelaskan, mengkaji dan memperdalam materi.

Pada level ini guru mengembangkan konsep yang sudah dikuasai oleh siswa atau menjalin hubungan antar konsep.

Teknik analisis data pada penelitian kualitatif melalui beberapa tahap. Tahap pertama reduksi, mengoreksi hasil pekerjaan siswa setelah itu dirangking untuk menentukan siswa yang akan dijadikan subjek penelitian, hasil dari pekerjaan siswa tersebut yang menjadi subjek penelitian, setelah itu hasil wawancara disederhanakan. Tahap kedua penyajian data, tahapan ini data hasil tes dianalisis dan disajikan dalam bentuk deskripsi, 
menyajikan hasil wawancara yang sudah direkam. Tahap ketiga yaitu penarikan kesimpulan, berdasarkan data dan hasil analisis.

\section{HASIL DAN PEMBAHASAN}

Adapun perlu memperbaiki kesalahan yang dilakukan oleh siswa sehingga siswa tidak membuat kesalahan yang sama dan siswa dapat menyelesaikan masalah dengan benar. Guru perlu membimbing siswa melalui kegiatan tanya jawab untuk memperbaiki kesalahan yang mereka buat. Berikut ini adalah deskripsi kerangka kerja yang digunakan untuk setiap kesalahan kontruksi konsep.

\section{A. Pseudo Contruction "Benar"}

Berikut ini adalah deskripsi kerangka kerja yang digunakan untuk kesalahan kontruksi konsep. Kesalahan untuk item nomor 1 dibuat oleh SE1 dan SE2. Wawancara dilakukan oleh peneliti subjek SE1 yang menemukan bahwa SE1 salah dalam menuliskan jawaban saat menyelesaikan soal.

1. Sebelum dilakukanya pemberian scaffolding

Kesalahan yang dilakukan oleh subjek pada soal nomor 1 karena subjek menuliskan jawaban benar tetapi setelah ditelusuri siswa salah dalam menuliskan jawaban dapat dilihat pada siswa menjawab luas permukaan kubus $=6 \times 14 \times 14=1.76 \mathrm{~cm}$. Berikut ini hasil pekerjaan subjek SE1 pada Gambar 1.

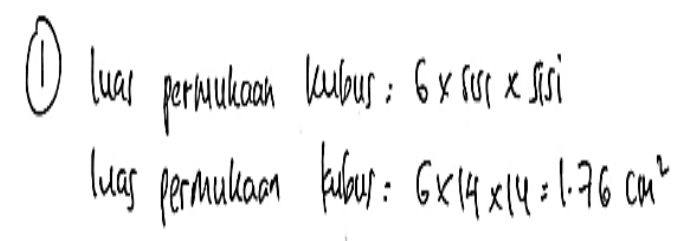

Gambar 1. Sebelum diberikan scaffolding pada soal kubus

\section{Pemberian bentuk scaffolding}

Berdasarkan wawancara, subjek SE1 menuliskan jawaban yang benar, namun dari hasil survey siswa salah menuliskan jawaban, sehingga scaffolding yang digunakan untuk mengoreksi kesalahan SE1 adalah dengan memberikan scaffolding pada levelnya conceptual development dimana peran guru membantu siswa dalam mengembangkan konsep yang sudah dikuasi siswa atau menjalanin hubungan antara konsep lain.

3. Setelah dilakukanya pemberian scaffolding

Setelah subjek memahami masalah dengan benar, peneliti mengajukan pertanyaan dengan jenis yang sama tetapi nomor yang berbeda, tetapi bekerja lagi tanpa bantuan peneliti. Gambar 2 menunjukkan hasil soal dan jawaban subjek.

Subjek SE1 mengerjakan soal tersebut dengan benar, maka proses scaffolding untuk indikator "pseudo contruction benar" untuk subjek SE1 dianggap selesai.

$$
\text { 1) Rumus luas permukcan kubus: } \begin{aligned}
& 6 \times(5 \times s) \\
& =6 s^{2} \\
\text { Luas permukaan kubus } & =6 s^{2} \\
& =(6 \times 14 \mathrm{~cm}) \times 14 \mathrm{~cm} \\
& =84 \times 14 \mathrm{~cm}^{2} \\
& =1.176 \mathrm{~cm}^{2}
\end{aligned}
$$

Gambar 2. Setelah diberikan scaffolding pada soal kubus

\section{B. Pseudo Contruction "Salah"}

Berikut ini adalah deskripsi kerangka kerja yang digunakan untuk kesalahan kontruksi konsep. Kesalahan yang dilakukan oleh subjek SE2. Wawancara dilakukan oleh peneliti dengan subjek SE2 bahwa SE2 
DOI: https://doi.org/10.24127/ajpm.v10i4.4151

menuliskan jawaban yang salah dalam menyelesaikan soal.

1. Sebelum dilakukannya pemberian scaffolding

Kesalahan yang dilakukan subjek pada soal nomor 1 karena subjek SE2 telah menuliskan jawaban yang salah siswa menjawab 6 x ( $14 \times 14)$ $(\mathrm{cm} \times \mathrm{cm})$. Berikut ini hasil pekerjaan subjek SE2 pada Gambar 3.

$$
\begin{aligned}
& \text { Jawab: } \\
& \text { (1) loar permokang tubus: } 6 \times 3^{2} \\
& : 6 \times(14 \times 14)(\mathrm{cm} \times \mathrm{cm})
\end{aligned}
$$

Gambar 3. Sebelum diberikan scaffolding pada soal kubus

\section{Pemberian bentuk scaffolding}

Berdasarkan hasil wawancara, subjek SE2 menuliskan jawaban yang benar, namun dari hasil survey, siswa salah menulis jawaban, sehingga scaffolding yang digunakan untuk mengoreksi kesalahan SE2 adalah untuk memberikan scaffolding pada level conceptual development dimana peran guru membantu siswa dalam mengembangkan konsep yang sudah dikuasi siswa atau menjalanin hubungan antara konsep lain.

3. Setelah dilakukanya pemberian scaffolding

Setelah subjek memahami masalah dengan benar, peneliti mengajukan pertanyaan dengan jenis yang sama tetapi nomor yang berbeda, tetapi bekerja lagi tanpa bantuan peneliti. Gambar 4 menunjukkan hasil soal dan jawaban subjek.
1. funmus luas Permukcan kubus: $\begin{aligned}: & 6 x(5 \times 5) \\ & : 65^{2}\end{aligned}$

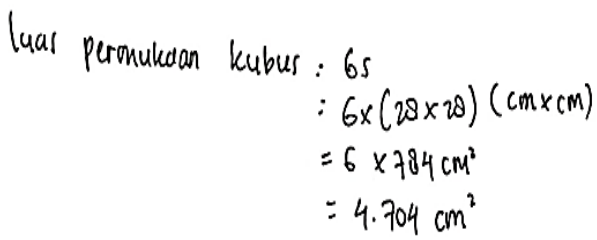

Gambar 4. Setelah diberikan scaffolding pada soal kubus

Subjek SE2 masih salah dalam mengerjakan soal tersebut dikarenakan SE2 belum bisa mengembangkan konsep yang sudah dikuasai atau menjalanin hubungan antar konsep yang lain. Maka proses scaffolding untuk indikator "pseudo contruction salah" untuk subjek SE2 belum berhasil.

\section{Lubang Kontruksi}

Berikut ini adalah deskripsi kerangka kerja yang digunakan untuk kesalahan kontruksi konsep. Kesalahan yang dilakukan oleh subjek SE1, SE2 dan SE3. Wawancara dilakukan oleh peneliti dengan subjek SE2 bahwa SE2 menuliskan jawaban benar, tetapi ada proses kontruksi konsep dalam siswa yang tidak cocok.

1. Sebelum dilakukanya pemberian scaffolding

Kesalahan yang dilakukan oleh subjek Soal 2 karena subjeknya SE2 menuliskan dalam proses mengerjakan seharusnya yang di dalam kurung terlebih dahulu yang dikerjakan seperti $2(500+250+400)=2(950)=$ $1.900 \mathrm{~cm}^{2}$. tetapi siswa mengerjakan seperti $2(500+250+200)=1000+$ $500+400=1.900 \mathrm{~cm}^{2}$. Berikut ini hasil pekerjaan subjek SE2 pada Gambar 5. 


$$
\begin{aligned}
& \text { (1) Inas permulican: } 2(p+p+1+16): 2(200+500+250) \\
& : 2(950) \\
& =\lg 000 \mathrm{~cm}^{3}
\end{aligned}
$$

Gambar 5. Sebelum diberikan Scaffolding pada soal kubus

\section{Pemberian bentuk scaffolding}

Berdasarkan wawancara terdapat subjek menuliskan jawaban benar, tetapi ada proses kontruksi konsep dalam siswa yang tidak cocok. Scaffolding yang digunakan untuk memperbaiki kesalahan SE2 adalah pemberian scaffolding pada level Explaining dimana peran guru adalah menjelaskan konsep ketika siswa tidak mengetahui atau melupakan. Siswa juga harus jelas tentang ide-ide mereka dan berpartisipasi aktif.

3. Setelah dilakukanya pemberian Scaffolding

Setelah subjek memahami masalah dengan benar, peneliti mengajukan pertanyaan dengan jenis yang sama tetapi nomor yang berbeda, tetapi bekerja lagi tanpa bantuan peneliti. Gambar 6 menunjukkan hasil soal dan jawaban subjek.

$$
\text { 2) } \begin{aligned}
\text { Rumus loas permukaan balok } & =p \times l \times t \\
& =\frac{25 \mathrm{~cm} \times 20 \mathrm{~mm} \times 10 \mathrm{~cm}}{2} \\
& =\frac{5000}{2} \\
& =2.500 \mathrm{~cm}^{3} \\
& =
\end{aligned}
$$

Gambar 6. Soal Setelah diberikan Scaffolding pada soal balok
Subjek SE2 mengerjakan soal tersebut dengan benar, maka proses scaffolding untuk indikator "lubang kontruksi” untuk subjek SE2 dianggap selesai.

\section{Mis Analogical Contruction}

Berikut ini adalah deskripsi kerangka kerja yang digunakan untuk kesalahan kontruksi konsep. Kesalahan yang dilakukan oleh subjek SE3. Wawancara dilakukan oleh peneliti dengan subjek SE3 bahwa SE3 menuliskan jawaban salah disebabkan siswa membandingkan sesuatu konsep dengan konsep lain.

1. Sebelum dilakukannya pemberian scaffolding

Kesalahan yang dilakukan subjek pada soal nomor 1 karena subjek SE3 menuliskan proses kontruksi yang salah pada luas permukaan kubus $=6 \mathrm{~s}^{2}=$ $(6 \times 14 \mathrm{~cm}) \times 14 \mathrm{~cm}=84 \times 14 \mathrm{~cm}^{2}=1.176$ $\mathrm{cm}^{2}$. Berikut ini hasil pekerjaan subjek SE3 pada Gambar 7.

1) Rumus luas permukaan kubus: $\begin{aligned} & 6 \times(5 x s) \\ : & 6 s^{2}\end{aligned}$

luas permukaan Kuhus: $65^{2}$

$$
\begin{aligned}
& =(6 \times 14 \mathrm{~cm}) \times 14 \mathrm{~cm} \\
& =84 \times 14 \mathrm{~cm}^{2} \\
& =1.176 \mathrm{~cm}^{2}
\end{aligned}
$$

Gambar 7. Sebelum diberikan scaffolding pada soal kubus

2. Pemberian bentuk scaffolding

Berdasarkan wawancara terdapat subjek SE3 menuliskan jawaban salah disebabkan siswa membandingkan sesuatu konsep dengan konsep yang lain. Scaffolding yang digunakan untuk memperbaiki kesalahan SE3 adalah scaffolding level Explaining dimana peran guru adalah menjelaskan konsep 
DOI: https://doi.org/10.24127/ajpm.v10i4.4151

jika siswa tidak mengetahui atau melupakan, dan siswa perlu mengklarifikasi pemikirannya dan berpartisipasi aktif.

3. Setelah dilakukannya pemberian scaffolding

Setelah subjek memahami masalah dengan benar, peneliti mengajukan pertanyaan dengan jenis yang sama tetapi nomor yang berbeda, tetapi tanpa bantuan peneliti. Gambar 8 menunjukkan hasil soal dan jawaban subjek.

$$
\begin{aligned}
\text { Jawab: } & \\
\text { (1) Luas permukaan kubus: } & 6 \times s^{2} \\
& =6 \times(14 \times 14)(\mathrm{cm} \times \mathrm{cm}) \\
& =6 \times 196 \mathrm{~cm}^{2} \\
& =1.176 \mathrm{~cm}^{2}
\end{aligned}
$$

Gambar 8. Setelah diberikan scaffolding pada soal kubus

Subjek SE2 mengerjakan soal tersebut dengan benar, maka proses scaffolding untuk indikator "lubang kontruksi" untuk subjek SE2 dianggap selesai.

\section{Mis logical contruction}

Kesalahan yang dilakukan oleh subjek SE3. Wawancara dilakukan oleh peneliti dengan subjek SE3 bahwa SE3 menuliskan jawaban salah disebabkan siswa tidak bisa menalar ataupun menguasai soal dengan benar.

\section{Sebelum Pemberian Scaffolding}

Kesalahan yang dilakukan subjek pada soal nomor 2 jawaban SE3 telah menuliskan jawaban salah yaitu tidak mampu dalam menguasai soal dengan benar yaitu dapat dilihat menuliskan rumus luas permukaan balok $=\mathrm{p} \times 1 \times \mathrm{t}$ $=25 \mathrm{~cm} \times 20 \mathrm{~cm} \times 10 \mathrm{~cm}$ dibagi $2=$
$5000 / 2=2.500 \mathrm{~cm}^{3}$. Berikut ini hasil pekerjaan subjek SE3 pada gambar 9.

2) Rumus luas permukcan bulde: $p \times \ell \times t$

$$
\begin{aligned}
& =\frac{25 \mathrm{~cm} \times 10 \mathrm{~cm} \times 10 \mathrm{~cm}}{2} \\
& =\frac{5000}{2} \\
& =2.500 \mathrm{~cm}^{2} .
\end{aligned}
$$

Gambar 9. Sebelum diberikan scaffolding pada soal balok

\section{Bentuk Pemberian Scaffolding}

Berdasarkan wawancara terdapat subjek SE3 menuliskan jawaban salah disebabkan siswa tidak bisa menalar ataupun menguasai soal dengan benar. Scaffolding yang digunakan untuk memperbaiki kesalahan SE3 yaitu scaffolding level Reviewing dimana peran guru adalah memfokuskan kembali perhatian, memberi lebih banyak kesempatan untuk memahami masalah, dan memecahkan masalah dengan pemahaman sendiri.

\section{Setelah Pemberian Scaffolding}

Setelah subjek memahami masalah dengan benar, peneliti mengajukan pertanyaan dengan jenis yang sama tetapi nomor yang berbeda, tetapi tanpa bantuan peneliti. Gambar 10 menunjukkan hasil soal dan jawaban subjek.

$$
\begin{aligned}
\text { 2) Rumus luas permukaan balok } & =p \times l \times t \\
& =\frac{25 \mathrm{~cm} \times 20 \mathrm{~cm} \times 10 \mathrm{~cm}}{2} \\
& =\frac{5000}{2} \\
& =2.500 \mathrm{~cm}^{3} \\
& =
\end{aligned}
$$

Gambar 10. Setelah diberikan scaffolding pada soal balok 
DOI: https://doi.org/10.24127/ajpm.v10i4.4151

Subjek SE2 masih salah dalam mengerjakan soal tersebut dikarenakan SE2 belum bisa mengembangkan konsep yang sudah dikuasai atau menjalanin hubungan antar konsep yang lain. Maka proses scaffolding untuk indikator "pseudo contruction salah" untuk subjek SE2 belum berhasil.
Adapun teknik analisis data penelitian ini Menurut (Cresswell, 2016) dilakukan dengan beberapa uji yang terdiri dari :

1. Reduksi data, yaitu pemilihan dan klasifikasi siswa yang melakukan kesalahan kontruksi konsep (Tabel 3) pada materi bangun ruang sisi datar.

Tabel 3. Hasil kesalahan kontruksi konsep siswa sebelum diberikan scaffolding

\begin{tabular}{|c|c|c|c|c|c|}
\hline Subjek & PCB & PCS & LB & МАС & MLC \\
\hline SE1 & $\begin{array}{l}\text { Terjadi } \\
\text { kesalahan }\end{array}$ & $\begin{array}{l}\text { Tidak terjadi } \\
\text { kesalahan }\end{array}$ & $\begin{array}{l}\text { Terjadi } \\
\text { kesalahan }\end{array}$ & $\begin{array}{l}\text { Tidak terjadi } \\
\text { kesalahan }\end{array}$ & $\begin{array}{l}\text { Tidak terjadi } \\
\text { kesalahan }\end{array}$ \\
\hline SE2 & $\begin{array}{l}\text { Terjadi } \\
\text { kesalahan }\end{array}$ & $\begin{array}{l}\text { Terjadi } \\
\text { kesalahan }\end{array}$ & $\begin{array}{l}\text { Terjadi } \\
\text { kesalahan }\end{array}$ & $\begin{array}{l}\text { Tidak terjadi } \\
\text { kesalahan }\end{array}$ & $\begin{array}{l}\text { Tidak terjadi } \\
\text { kesalahan }\end{array}$ \\
\hline SE3 & $\begin{array}{l}\text { Tidak terjadi } \\
\text { kesalahan }\end{array}$ & $\begin{array}{l}\text { Tidak terjadi } \\
\text { kesalahan }\end{array}$ & $\begin{array}{l}\text { Terjadi } \\
\text { kesalahan }\end{array}$ & $\begin{array}{l}\text { Terjadi } \\
\text { kesalahan }\end{array}$ & $\begin{array}{l}\text { Terjadi } \\
\text { kesalahan }\end{array}$ \\
\hline
\end{tabular}

2. Penyajian data, yaitu melakukan datar berdasarkan pemberian penyusunan jenis kesalahan kontruksi scaffolding (Tabel 4).

konsep pada materi bangun ruang sisi

Tabel 4. Indikator kesalahan kontruksi konsep dan pemberian scaffolding

\begin{tabular}{lll}
\hline Subjek & \multicolumn{1}{c}{ Indikator Kesalahan Kontruksi Konsep } & \multicolumn{1}{c}{$\begin{array}{c}\text { Pemberian } \\
\text { Scaffolding }\end{array}$} \\
\hline SE1 & Pseudo Contruction "Benar" & Conceptual Development \\
& Lubang Kontruksi & Explaining \\
SE2 & Pseudo Contruction "Benar" & Conceptual Development \\
& Pseudo Contruction "Salah" & Conceptual Development \\
& Lubang Kontruksi & Explaining \\
SE3 & Lubang Kontruksi & Explaining \\
& Mis-analogical Contruction & Restructuring \\
& Mis-logical Contruction & Reviewing \\
\hline
\end{tabular}

3. Menarik Kesimpulan yaitu hasil kesalahan kontruksi setelah melakukan kegiatan atau pemberian scaffolding yang sesusai dengan kesalahan kontruksi konsep yang dilakukan masing-masing siswa (Tabel 5).

Hasil dari penelitian ini bahwa pemberian scaffolding itu dapat membantu untuk mengatasi kesalahan kontruksi konsep siswa. Hal ini dikarenakan guru memberikan bantuan scaffolding berdasarkan level scaffolding yang diberikan yaitu conceptual development, explaing, restricting, dan reviewing berdasarkan yang cocok untuk indikator kesalahan kontruksi konsep siswa. Tujuan diterapkannya scaffolding untuk menggambarkan jenis dukungan terhadap proses yang memungkinkan siswa untuk menyelesaikan masalah, melaksanakan tugas atau mencapai tujuannya 
DOI: https://doi.org/10.24127/ajpm.v10i4.4151

Tabel 5. Hasil kesalahan kontruksi konsep siswa sesudah diberikan scaffolding

\begin{tabular}{|c|c|c|c|c|c|}
\hline Subjek & PCB & PCS & LB & МАС & MLC \\
\hline $\begin{array}{l}\text { SE1 } \\
\end{array}$ & $\begin{array}{l}\text { Tidak terjadi } \\
\text { kesalahan }\end{array}$ & $\begin{array}{l}\text { Tidak terjadi } \\
\text { kesalahan }\end{array}$ & $\begin{array}{l}\text { Tidak terjadi } \\
\text { kesalahan }\end{array}$ & $\begin{array}{l}\text { Tidak terjadi } \\
\text { kesalahan }\end{array}$ & $\begin{array}{l}\text { Tidak terjadi } \\
\text { kesalahan }\end{array}$ \\
\hline SE2 & $\begin{array}{l}\text { Tidak terjadi } \\
\text { kesalahan }\end{array}$ & $\begin{array}{l}\text { Masih terjadi } \\
\text { kesalahan }\end{array}$ & $\begin{array}{l}\text { Tidak terjadi } \\
\text { kesalahan }\end{array}$ & $\begin{array}{l}\text { Tidak terjadi } \\
\text { kesalahan }\end{array}$ & $\begin{array}{l}\text { Tidak terjadi } \\
\text { kesalahan }\end{array}$ \\
\hline SE3 & $\begin{array}{l}\text { Tidak terjadi } \\
\text { kesalahan }\end{array}$ & $\begin{array}{l}\text { Tidak terjadi } \\
\text { kesalahan }\end{array}$ & $\begin{array}{l}\text { Tidak terjadi } \\
\text { kesalahan }\end{array}$ & $\begin{array}{l}\text { Tidak terjadi } \\
\text { kesalahan }\end{array}$ & $\begin{array}{l}\text { Masih terjadi } \\
\text { kesalahan }\end{array}$ \\
\hline
\end{tabular}

Berdasarkan literature hasil penelitian sebelumnya yang dilakukan (Ni \& Fathani, 2018) mengetahui jenis kesalahan konstruksi konsep matematika yang dilakukan siswa meliputi: (1) pseudo development, (2) lubang konstruksi, (3) mis-analogical development, dan (4) mis logical development. Kesalahan siswa dalam merumuskan konsep matematika perlu dibenahi. Salah satunya dengan menyediakan scaffolding sesuai dengan kebutuhan siswa. Menyediakan scaffolding membantu siswa mengembangkan pola pikir untuk menemukan hasil akhir yang tepat. Hal ini sejalan dengan penelitian yang dilakukan oleh (Susilowati \& Ratu, 2018) menemukan kesalahan siswa saat memecahkan masalah dan dapat memberikan dukungan bagi siswa yang mengalami kesulitan atau membuat kesalahan dalam belajar matematika atau materi lainnya.

Kelebihan dari scaffolding membantu kegagalan siswa dalam perkembangan kognitif, keberuntungan diri, dan menghargai diri. Manfaat dari scaffolding yaitu meminimalkan tingkat frustasi siswa, memotivasi siswa untuk belajar, melatih berpikir kritis dan meningkatkan kemampuan berpikir mandiri dan kelompok. Dengan berpartisipasi aktif dalam proses pembelajaran berbasis penelitian tentang masalah yang diangkat oleh guru, siswa dapat memecahkan masalah dan menikmati proses pembelajaran dikelas. Hal ini merupakan faktor yang mempengaruhi pemahaman konsep siswa pada pembelajaran scaffolding, yang berbeda nyata dengan peningkatan pemahaman konsep siswa yang belajar pada pembelajaran tradisional. Adapun kekurangan dari scaffolding sulitnya guru membuat rencana scaffolding dan sulitnya memetakan ZPD setiap siswa, menghabiskan banyak waktu.

Strategi scaffolding dapat dipilih guru untuk membantu kesulitan siswa dalam belajar. Kesulitan belajar pasti dialami siswa terutama ketika menghadapi materi atau informasi baru. Scaffolding juga dapat dilakukan oleh setiap guru, orang dewasa atau orang ahli dalam kesehariannya. Agar scaffolding dapat berjalan dengan benar dan efektik maka perlu mendapatkan pelatihan dan pengalaman yang cukup. Scaffolding memiliki kelebihan dan kelemahan maka guru perlu memanfaatkan kelebihan yang ada dan mengurangi kekurangannya.

\section{KESIMPULAN DAN SARAN}

Berdasarkan hasil penelitian yang telah dilakukan indikator kesalahan kontruksi konsep, kesalahan untuk indikator pseudo contruction "benar" kesalahan terjadi pada SE1 dan SE2. Untuk indikator pseudo contruction "salah hanya terjadi pada SE2. Untuk indikator lubang kontruksi terjadi pada semua subjek. Untuk indikator mis-analogical contruction dan indikator mis-logical contruction hanya terjadi pada SE3. 
DOI: https://doi.org/10.24127/ajpm.v10i4.4151

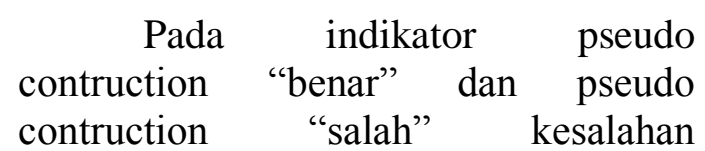
dikarenakan siswa kurang teliti dalam proses mengerjakan soal. Pada lubang kontruksi kesalahan dikarenakan siswa belum memahami kontruksi konsep. Sedangkan pada indikator misanalogical contruction kesalahan dikarenakan siswa salah dalam menentukan rumus yang sesuai. Pada indikator mis-logical contruction kesalahan dikarenakan siswa kurang teliti dalam menghitung.

Untuk kesalahan kontruksi konsep pada indikator pseudo contruction "Benar" seperti yang terjadi pada SE1 dan SE2 scaffolding yang sesuai adalah tahap conceptual development. Untuk indikator pseudo contruction "Salah" seperti yang terjadi pada SE1 scaffolding yang sesuai adalah tahap conceptual development. Untuk indikator lubang kontruksi seperti yang terjadi pada semua subjek scaffolding yang sesuai adalah tahap Explaining. Untuk indikator misanalogical contruction seperti yang terjadi pada SE3 scaffolding yang sesuai adalah tahap restructuring. Untuk indikator mis-logical contruction seperti yang terjadi pada SE3 scaffolding yang sesuai adalah tahap Reviewing.

Berdasarkan hasil penelitian yang telah dilaksanakan, adapun saran dari penulis Guru harus mampu mengidentifikasi kekurangan pada desain konseptual yang dibuat siswa dalam menyelesaikan masalah dan memberikan scaffolding bagi siswa yang mengalami kesulitan atau kekurangan dalam mempelajari bangun ruang sisi datar dan materi lain yang ada. Bagi peneliti ini diharapkan dapat menjadi gambaran untuk penelitian selanjutnya mengenai kesalahan kontruksi konsep dalam menyelesaikan soal bangun ruang sisi datar dan pemberian scaffolding.

\section{DAFTAR PUSTAKA}

Abdu, R., Schwarz, B., \& Mavrikis Manolls. (2015). Perancah seluruh kelas untuk belajar memecahkan masalah matematika bersama-sama dalam lingkungan yang didukung komputer. ZDM - Mathematics Education, $\quad 1, \quad 3$. https://doi.org/DOI 10.1007 / s11858-015-0719-y

Amelia, S. R., Anwar, C., \& Firdos, H. (2021). Kontruksi Konsep Sistem Persamaan Linier Tiga Variabel Bagi Siswa SMA Berdasarkan Teori Apos. Jurnal Inovasi Dan Riset, 2(1), 44-58.

Bakker, A. (2015). Scaffolding and dialogic teaching in mathematics education: introduction and review. ZDM - Mathematics Education, 47(7), 1047-1065. https://doi.org/10.1007/s11858015-0738-8

Baranovich, D., Fong, P., \& Hutagalung, F. (2017). Parental Scaffolding dalam Matematika Pekerjaan Rumah di antara Anakanak Prasekolah Swasta Malaysia : Studi Kasus. Int J of Sci and Math Educ, 2(13-14). https://doi.org/DOI 10.1007 s10763-017-9850-2

Brower, R. L., Woods, C. S., Jones, T. B., Park, T. J., Hu, S., Tandberg, D. A., ... Martindale Sophia G. Rahming \& Sandra K. (2017). Remediasi Matematika Scaffolding untuk Siswa Berisiko Akademik Setelah Reformasi Pendidikan Perkembangan di Florida Remediasi Matematika Scaffolding 
DOI: https://doi.org/10.24127/ajpm.v10i4.4151

Untuk Akademik Di -Risiko. Community College Journal of Research and Practice, 8926. https://doi.org/http://dx.doi.org/10. 1080/10668926.2017.1279089

Cresswell. (2016). on the move: mobility in the modern westem word. francis: Taylor.

Damayanti, N. W. (2016). Praktik Pemberian Scaffolding Oleh Mahasiswa Pendidikan Matematika Pada Mata Kuliah Strategi Belajar Mengajar ( Sbm ) Matematika. Jurnal Ilmiah Fakultas Keguruan Dan Ilmu Pendidikan, 18, 85-95.

Faradillah, A., \& Febriani, L. (2021). Mathematical Trauma Students, Junior High School Based on Grade and Gender. Journal of Mathematcs Education, 10(1), 5368.

https://doi.org/https://doi.org/10.22 460/infinity.v10i1.p53-68

Kamid \& yuliya, S. (2020). Pengembangan Modul Panduan Guru Matematika Dalam Mendesain Pembelajaran PjBL Berbasis Budaya Jambi. AKSIOMA: Jurnal Program Studi Pendidikan Matematika, 9(2), 424-432.

https://doi.org/https://doi.org/10.24 127/ajpm.v9i2.2796

Kemendikbud. (2017). Buku guru matematika kelas VIII SMP/Mts kurikulum 2013 edisi revisi 2017. Kemendikbud.

Komarudin. (2016). Analisis Kesalahan Pemecahan Masalah Matematika pada Materi Peluang Berdasarkan High Order Thinking. Jurnal Pendidikan, Komunikasi Dan
Pemikiran Hukum Islam, VIII(1), 202-217.

Kristanti Dian. (2020). Scaffolding Sebagai Upaya Mengatasi Kesalahan Matematika Siswa Kelas Viii. Jurnal Pendidikan Matematika Dan Matematika, 2 (1), 54-65. https://doi.org/https://doi.org/10.30 736/vj.v2il.193

Kusmaryono, I., Ubaidah, N. (2020). The role of scaffolding in the deconstructing of thinking structure: a case study of pseudothinking process. Journal of Mathematcs Education, 9(2). https://doi.org/https://doi.org/10.22 460/infinity.v9i2.p247-262

Ni'mah, R., Sunismi, \& Fathani, A. H. (2018). Kesalahan Konstruksi Konsep Matematika Dan Scaffolding -Nya Construction Error Of Mathematical Concepts. Jurnal Pendidikan Dan Pembelajaran, 3(2), 162-171.

Ni, R., \& Fathani, A. H. (2018). Kesalahan Konstruksi Konsep Matematika dan Scaffolding -Nya Construction Error of Mathematical Concepts. 3(2), 162171.

Sari, A. K., \& Trisnawati, W. (2019). Integrasi Keterampilan Abad 21 Dalam Modul Sociolinguistics : Keterampilan 4c ( Collaboration , Communication, Critical Thinking, Dan Creativity ). Jurnal Muara Pendidikan, 4(2), 455-466.

Suratno, J., \& Sari, Prawitha, D. (2021). Analisis Komparatif Kurikulum Matematika Di Indonesia Korea Selatan, dan Singapura Pada Jenjang Sekolah Menengah Atas. 
DOI: https://doi.org/10.24127/ajpm.v10i4.4151

\section{Jurnal Pendidikan Guru} Matematika, 1(1), 64-72.

Susilowati, P. L., \& Ratu, N. (2018). Analisis Kesalahan Siswa Berdasarkan Tahapan Newman Dan Scaffolding Pada Materi Aritmatika Sosial. Mosharafa: Jurnal Pendidikan Matematika, 7(1), 199-206.
Sutiarso, S. (2009). Scaffolding dalam Pembelajaran Matematika. Pendidikan dan Penerapan MIPA, 2(1991), 527-530. 